\title{
Paleoseismic evidence for coseismic growth-fold in the 1999 Chichi earthquake and earlier earthquakes, central Taiwan
}

\author{
Wen-Shan Chen ${ }^{\text {a,* }}$, Kun-Jie Lee ${ }^{\text {a }}$, Long-Sheng Lee ${ }^{\mathrm{a}}$, Ashley R. Streig ${ }^{\mathrm{b}}$, Charles M. Rubin ${ }^{\mathrm{b}}$, \\ Yue-Gau Chen ${ }^{\mathrm{a}}$, Hsiao-Chin Yang ${ }^{\mathrm{a}}$, Hui-Cheng Chang ${ }^{\mathrm{c}}$, Chii-Wen Lin ${ }^{\mathrm{c}}$ \\ ${ }^{a}$ Department of Geosciences, National Taiwan University, Taipei 106, Taiwan, ROC \\ ${ }^{\mathrm{b}}$ Department of Geological Sciences, Central Washington University, USA \\ ${ }^{\mathrm{c}}$ Central Geological Survey, Ministry of Economic Affairs, Taiwan, ROC
}

Received 22 July 2004; received in revised form 14 February 2006; accepted 27 July 2006

\begin{abstract}
The 1999 Chichi earthquake ruptured along previously unrecognized traces of the Chelungpu fault, because the traces were covered with thick-bedded fluvial, alluvial, and colluvial deposits. The earthquake created a 95-km-long surface rupture and associated faultrelated fold scarps. This study focused on the fault-related fold at two locations, where the fold scarp is characterized with trench excavation and shallow cored boring results. The structural characteristics revealed by the two trench sites are consistent with a trishear fault-propagation fold growth above a blind thrust. Several characteristics of the fold observed in the Holocene deposits show smoothly rounded fold-hinges, unconformities, onlapped structure, and downward steepening of forelimb strata. Results from these structures suggest that the fold grows by progressive limb rotation of growth strata in sequential coseismic growth episodes. The growth strata show several unconformable contacts as indicated by paleosoil horizons developed on event horizons. Based on the syntectonic sedimentary structure, three events are revealed at the Siangong-Temple site and two paleoearthquake events on the Shijia site. Integration with the two trenches and the previous studies suggests the three paleoearthquake events occurred 300-430, 710-800, and 1710-1900 yr B.P. These data on the two trench sites indicate that the average slip rate is 4.2 and $4.5 \mathrm{~mm} / \mathrm{yr}$, respectively.
\end{abstract}

(C) 2007 Elsevier Ltd. All rights reserved.

Keywords: Paleosismology; Chichi earthquake; Chelungpu fault; Growth fold; Recurrence interval

\section{Introduction}

The September 21, 1999 earthquake produced a 95-kmlong surface rupture (Fig. 1; Central Geological Survey, 1999; Chen et al., 2000, 2001c,d,e). During the twentieth century only a few large seismic ruptures have been well documented along a continental reverse fault (Philip and Meghraoui, 1983; Stein and King, 1984). Among them, the September 1999 Chichi rupture is likely the most comprehensively studied thrust rupture. Based on seismic reflection profiles and focal mechanisms of the mainshock, the earthquake occurred on a shallow-dipping $\left(20-30^{\circ} \mathrm{E}\right)$ thrust

\footnotetext{
* Corresponding author. Tel.: +8862369 2594; fax: +88623636095.

E-mail address: wenshan@ntu.edu.tw (W.-S. Chen).
}

ramp of the Chelungpu fault (Fig. 1; Chiu, 1971; Kao and Chen, 2000; Chen et al., 2001d; Wang et al., 2002). This shallow fault dip is consistent with the inferred dip of the fault as determinated by paleoseismic and subsurface cored borings (Chen et al., 2001a,b, 2004; Ota et al., 2001, 2005).

Our paper presents paleoseismic results along the Chichi earthquake surface rupture where we describe the various deformation styles that characterize the Chelungpu fault. Because active thrust faults commonly show complex geometric patterns of faulting and folding (Deng et al., 1996; Chen et al., 2001a,b, 2004), we present a few examples of excavations that document different styles of surface faulting along the Chelungpu fault (Fig. 1). Some paleoseismic excavations exposed a monoclinal fold in Holocene sediments that produced vertical relief and a gentle fault scarp (Lee, 2003). Holocene alluvial deposits show increased dip downward 


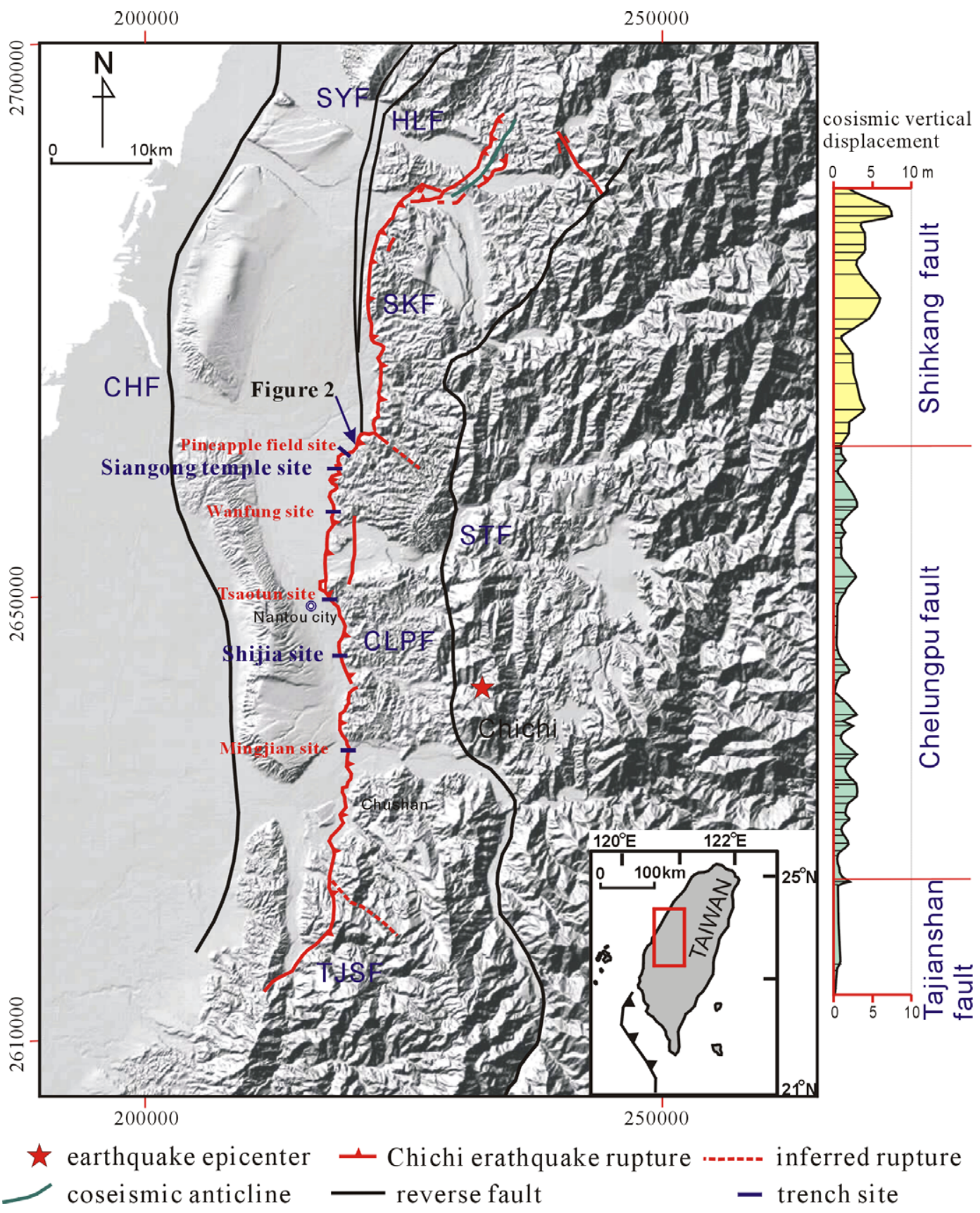

Fig. 1. Coseismic surface deformation during the 1999 Chichi earthquake dividing three segments along the Shihkang, Chelungpu, and Tajianshan faults had a sinuous trace that followed the frontal Western Foothills. Most excavations were located at the Chelungpu fault including the Siangong-Temple and Shijia sites. Location of Fig. 2 also shown. CHF, Changhuang fault; CLPF, Chelungpu fault; HLF, Houli fault; SKF, Shihkang fault; STF, Shuangtung fault; SYF, Sanyi fault; TJSF, Tajianshan fault.

which implies deformation of syntectonic sediments due to folding. Trench-wall exposures suggest that the surface deformation was produced by a propagating fault. Previous paleoseismological studies determined that four large earthquakes (including the Chichi earthquake) occurred in the past 1900 years (Chen et al., 2001a,b, 2004; Ota et al., 2001).

\section{Character of the Chichi earthquake rupture}

The active trace of the Chelungpu fault was identified at only one site before the earthquake (Fig. 2), because the fault was obscured by recent alluvial and colluvial deposits (Chen et al., 2000). In this location, late Pliocene shale is thrust over Holocene fluvial deposits (Fig. 2); vertical displacement was about $0.8 \mathrm{~m}$ during the Chichi earthquake. The Chichi earthquake, however, produced a clear surface rupture for about $95 \mathrm{~km}$ along the foothills. Landforms along the fault indicate recent displacement. Holocene terraces of vertical elevation are only developed on the hanging wall, and the 1999 rupture closely followed the foothills front along the terrace scarps (Chen et al., 2002, 2003a, 2004). Previous paleoseismic studies documented at least three large paleoearthquakes along the 


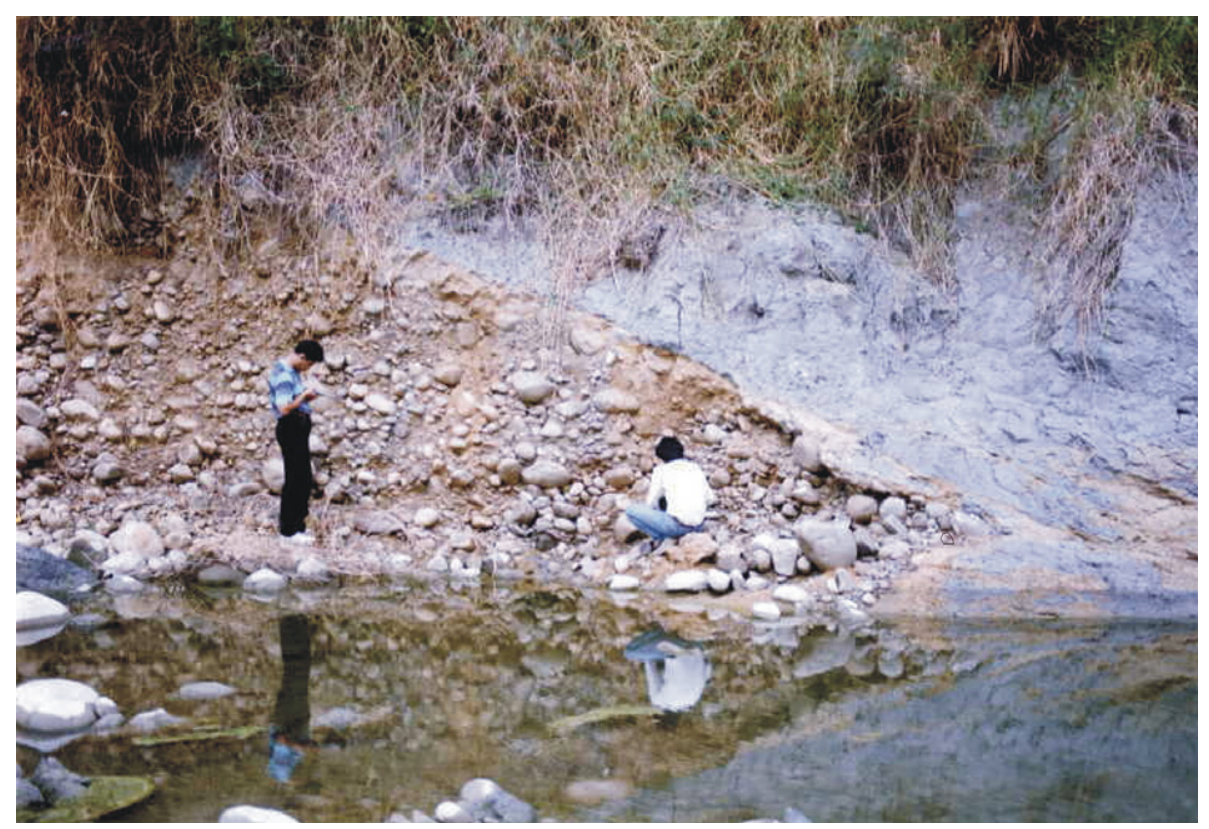

Fig. 2. The photograph of the Chelungpu fault taken in 1997 before the Chichi earthquake, which shows Pliocene shale overthrust on Holocene alluvial deposits. The vertical uplift along the fault plane during the Chichi earthquake was $0.8-\mathrm{m}$-high at this location.

Chelungpu fault during the late Holocene (Chen et al., 2001d,e, 2002, 2003a, 2004). Terraces on the hanging wall at the leading edge of the Chelungpu fault are interpreted to reflect rapid uplift, supported by paleoseismic studies that suggested a fault slip rate of about $8.5 \mathrm{~mm} / \mathrm{yr}$ for the past 1900 years (Chen et al., 2004).

Characteristics of the surface ruptures suggest the Chelungpu fault consist of three segments with different slip directions and vertical displacements indicate $\mathrm{N} 30^{\circ}-40^{\circ} \mathrm{W}$, $3-8 \mathrm{~m}$ of the Shihkang fault, $\mathrm{N} 70^{\circ}-90^{\circ} \mathrm{W}, 0.2-4 \mathrm{~m}$ of the Chelungpu fault, and $\mathrm{N} 50^{\circ} \mathrm{E}$ (right-lateral strike slip fault), $0.2-1 \mathrm{~m}$ of the Tajianshan fault (Fig. 1; Chen et al., 2001d). A bedding-slip fault within Pliocene shale characterizes the Shihkang fault, whereas the Chelungpu fault juxtaposes Pliocene shale and Late Quaternary conglomerate/sandstone deposits (Chen et al., 2001d,e).

\section{Paleoseismologic study}

Repeated coseismic displacements commonly display tectonic-geomorphic features related to displace Holocene sediments forming a fault scarp. After the earthquake, it was difficult to determine if these scarps were fault or fold related. We excavated five sites along the Chichi earthquake rupture (Fig. 1), and present two sites with syntectonic sedimentary strata that highlight the evolution of fault-related folding. Both excavations show a monoclinal fold, where the fault tip did not propagate through the surface deposits. Coseismic uplift during the Chichi earthquake produced 1- to 2-m-high fold scarps. We describe two representative trench-wall exposures and data from continuously cored borings and discuss the character of rupture by surface folding and provide a quantitative determination of the dip of the uppermost part of the fault.

\subsection{Siangong-Temple site}

The Chichi earthquake rupture cuts through the foot of a hill slope and produced a gentle 1-m-high monoclinal scarp. The existing ground surface apart from the fold scarp exhibits a gentle westward-dipping slope of approximately $2^{\circ}$. We excavated two 4- to 6-m-deep, 38-m-long trenches across the Chichi earthquake fold scarp (Figs. 3 and 4). Trench-wall exposures consist of five alluvial units that formed a wedge-shaped deposit associated with deposition across the scarp (Fig. 4). A distinctive paleosoil horizon overprints the top of each alluvial unit (e.g., Os1, Os2, Os3, Os4, and Os5 in Figs. 4 and 5). These paleosoils are unconformably overlain by gravel (aw1, aw2, and aw3) that onlap upwards onto the top of the west-dipping surface of Os2, Os3, and Os4 (Figs. 4 and 5). The gravel beds of unit aw2, for example, pinch out over the Os3 paleosoil of the forelimb or were eroded on the uplifted side of the fold. However, based on onlapping relations, the alluvium was deposited across the forelimb of a monoclinal coseismic fold scarp, and at times onlapped against it. Unit aw1 decreases in thickness from $1.8 \mathrm{~m}$ to several tens centimeters toward the limb (Fig. 5). The dips of paleosoil layers in the forelimb increase from $11^{\circ}$ at the ground surface to $38^{\circ}$ at the lower paleosoil layer (Os5). Upward change of dips, hindward thinning, and angular unconformites between paleosoils and overlying alluvium are interpreted as indicating repeated large earthquakes on the Chelungpu fault.

Two continuously cored borings were drilled to depth of $40 \mathrm{~m}$ on the hanging wall and $50 \mathrm{~m}$ on the footwall. The cored borings constrain the location of the fault zone on the hanging wall at a depth of $22.8 \mathrm{~m}$ between Pliocene shale and late Pleistocene-Holocene alluvial deposits. Based on the depth of the fault zone and location of fold 


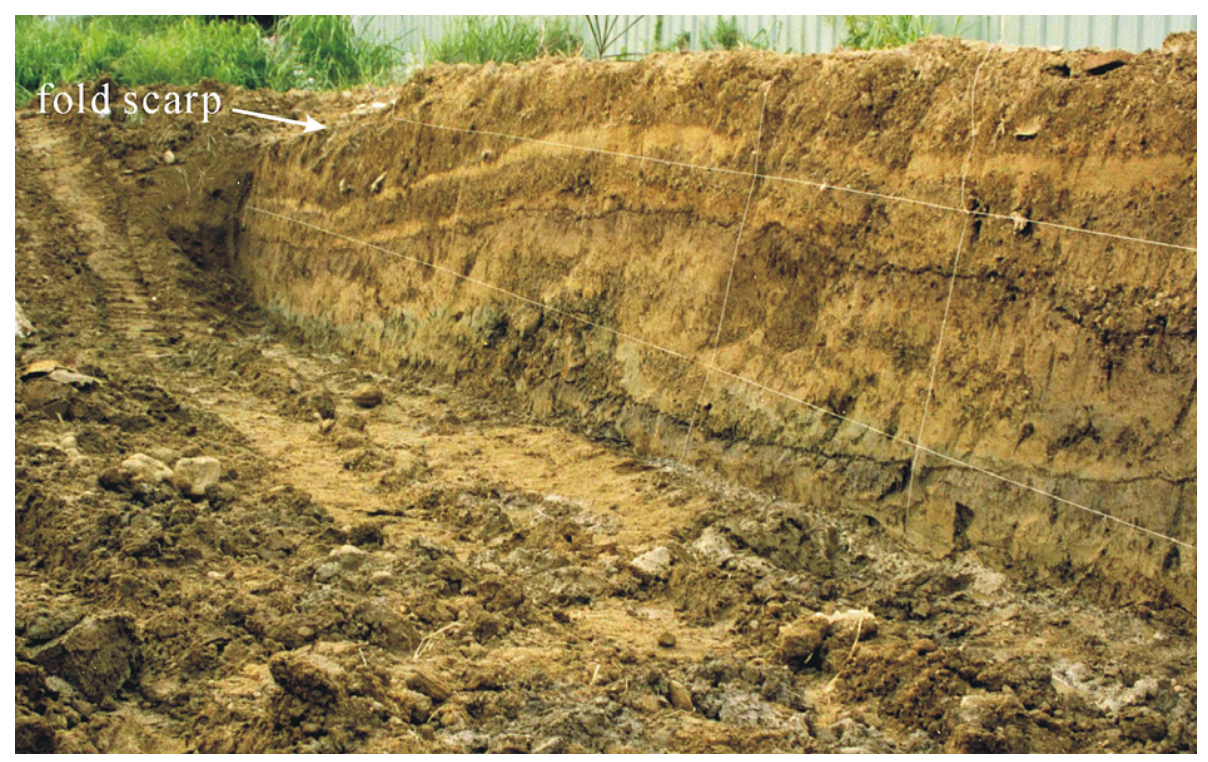

Fig. 3. The Siangong-Temple trenching profile shows a monoclinal fold with a gently dipping west-facing forelimb of approximately $11^{\circ}$ that formed during the Chichi earthquake.

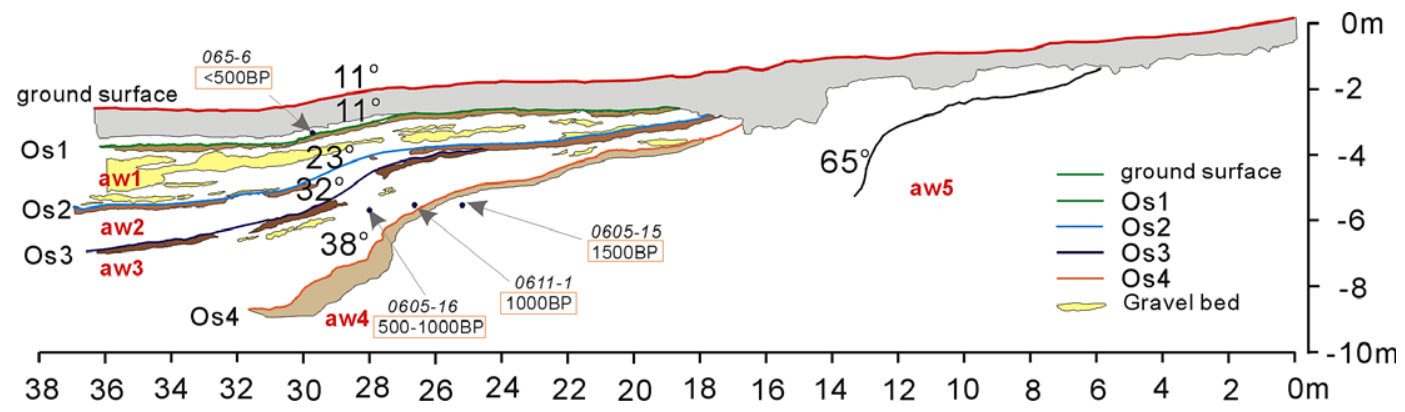

Fig. 4. Soils (Os1, Os2, Os3, and Os4) can provide useful controls on the interpretation of trench stratigraphy which bound three alluvial wedges (aw1, aw2, and aw3) representing three episodic seismic events.

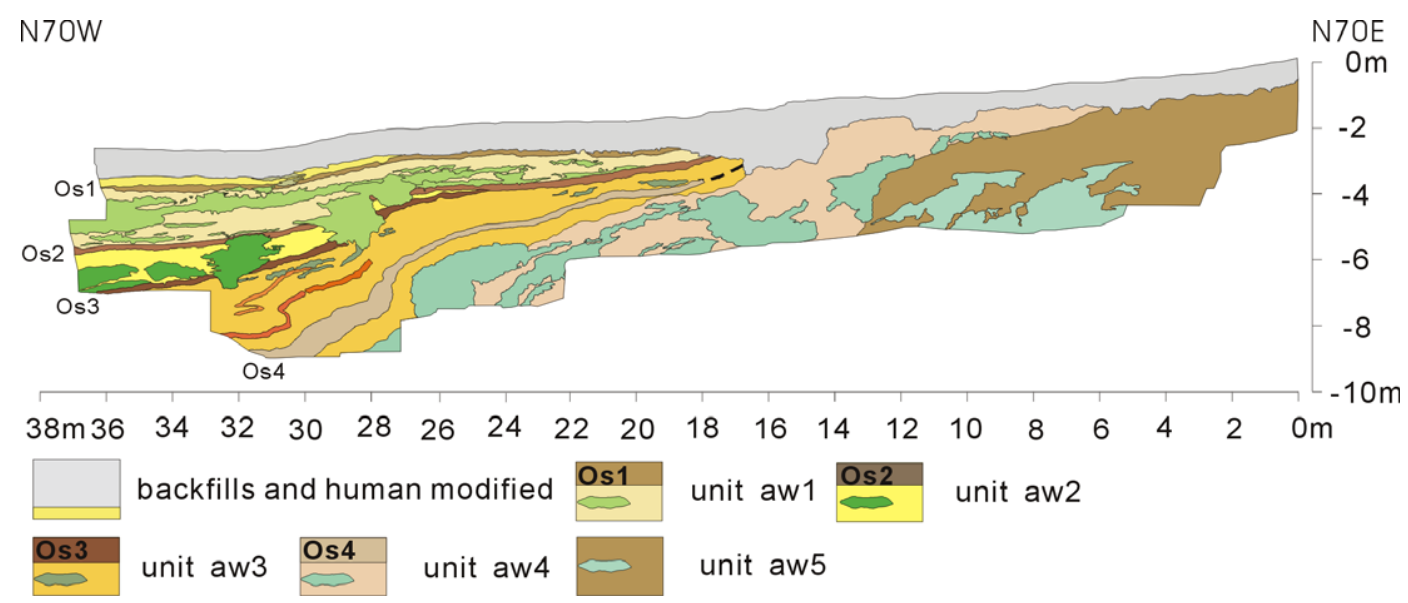

Fig. 5. Sketch of trench-wall emphasizing the top of beds of paleosoil (Os) and gravel depositional wedges (aw). The dips of paleosoil within the forelimb increase from $11^{\circ}$ to $38^{\circ}$ and show a fanning of bed dips. Alluvial gravels onlap onto each paleosoil horizon forming a wedge-shaped depositional unit. Radiocarbon date (sample 0120-3) is used to constrain the lower limit timing of N-3 event.

scarp, the fault must dip about $30^{\circ} \mathrm{E}$ along the shallowest portion of the thrust ramp (Fig. 6). Lithologic characteristics reveal two depositional sequences of fluvial and alluvial deposits in boreholes and trench excavations (Fig. 6). The two sequences represent a drastic change in the local depositional environment, with the upper sequence of sandstone 


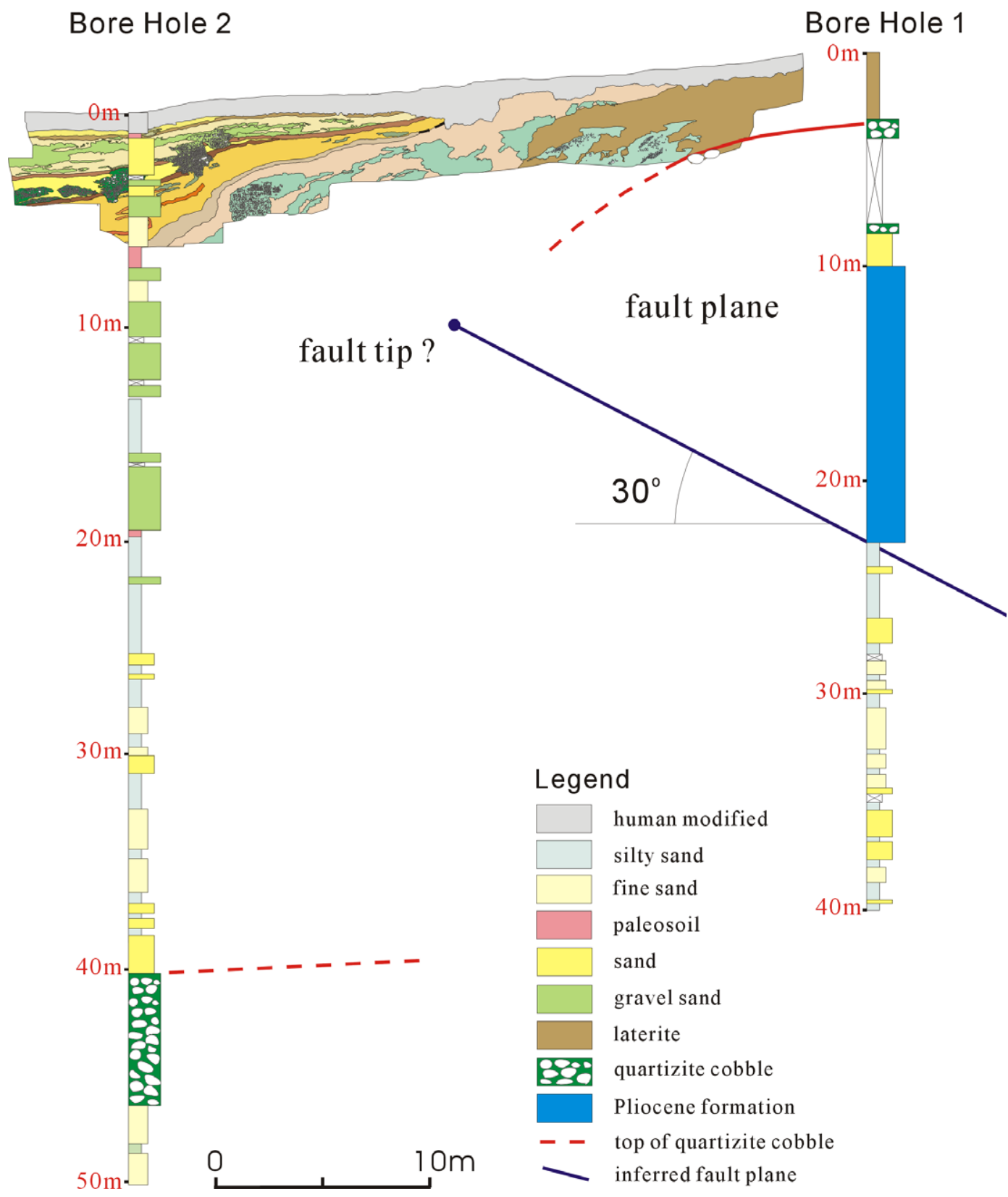

Fig. 6. Well logs reveal a shear zone at the bottom of Pliocene formation which shows inclined bed and slightly shearing at the Siangong-Temple site (Figs. 1 and 3). Correlation with a shear zone at depth in the two boreholes identifies a fault-plane dipping of $30^{\circ}$. The fluvial quartizite cobble deposits interpret to be offset about 40-m-high on both sides of the fault.

and gravel beds representing alluvial deposits derived from the hanging wall strata. The lower sequence consists of quartzite boulder conglomerate and represents fluvial deposition. The quartzite conglomerate bed shows about $38 \mathrm{~m}$ of vertical separation across the fault (Fig. 6).

\subsection{Shijia trench site}

The Shijia site is located along the frontal foothills, near Nantou city. The site is located on an alluvial fan exhibiting a gentle westward-dipping slope of approximately $3^{\circ}$, within which a distinctive 1- to 2-m-high gently dipping coseismic fold scarp formed during the earthquake (Fig. 7).
We excavated a 7-m-deep, 27-m-long trench across the Chichi earthquake fold scarp (Figs. 7 and 8). Shallow subsurface deposits consist predominantly of well-sorted fine sand interbedded with mud and humic paleosoil that represent overbank deposits. Trench-wall exposures show three depositional units (cw1, cw2, and $\mathrm{cw} 3$ ) defined by onlap of humic paleosoil horizons ( $\mathrm{H} 1$ and $\mathrm{H} 2$, Figs. 8 and 9). The lower sequence of unit cw3 consists of 5-m-thick alternating thick-bedded silt with thin-bedded mud and humic paleosoil horizons (Figs. 8 and 9). The upper sequence includes two wedge-shaped alluvial deposits of units cwl and $\mathrm{cw} 2$, which are exposed at the base of the monoclinal fold in the trench-wall exposures. The two units onlap $\mathrm{H} 1$ 


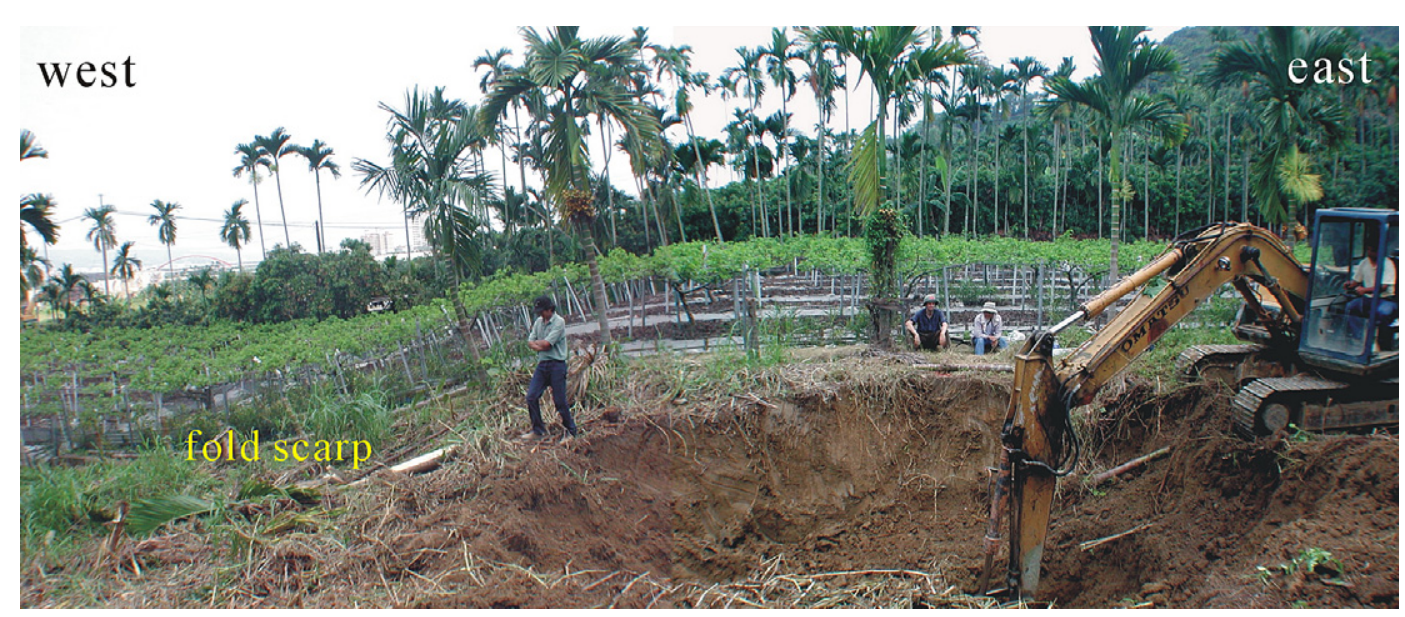

Fig. 7. Shijia site (custard apple field) displays a curved monoclinal surface due to the Chichi earthquake. Betel palm trees on the earthquake folded scarp were tilted. Topographic relief created of the site is 0.8 -m-high.

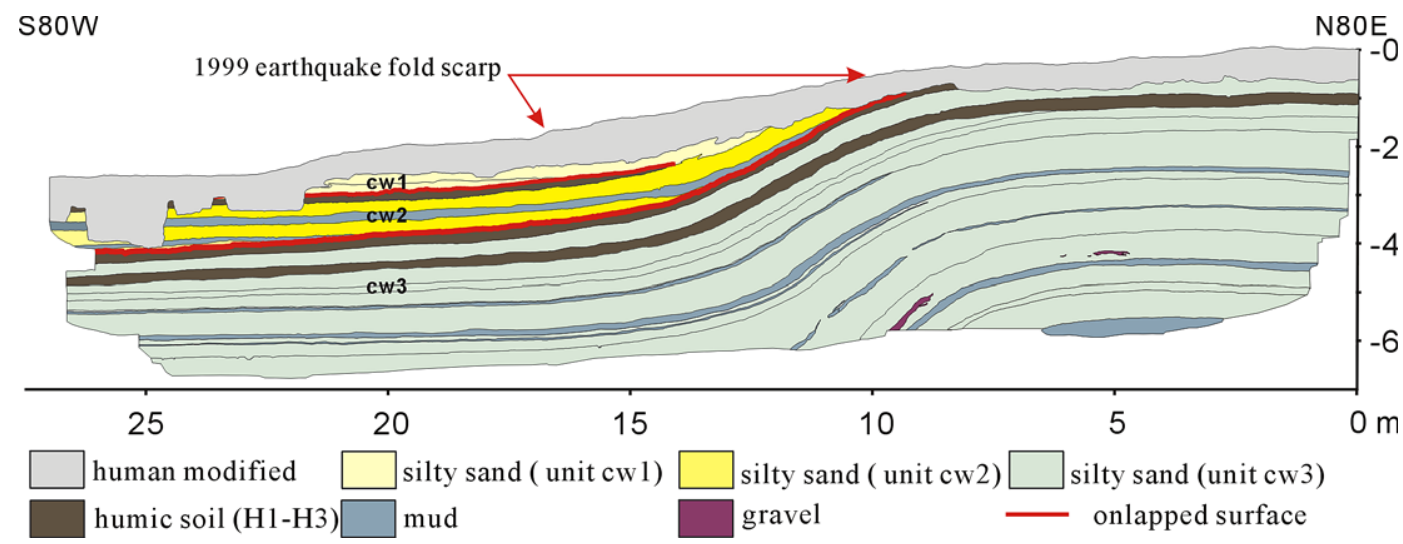

Fig. 8. The 1999 earthquake formed a westward-dipping scarp dipping approximately $9^{\circ}$. The contact of alluvial deposits and humic paleosoil (H-1 and $\mathrm{H}-2$ ) occurs a distinct onlapped structure interpreted to represent a paleoearthquake event.

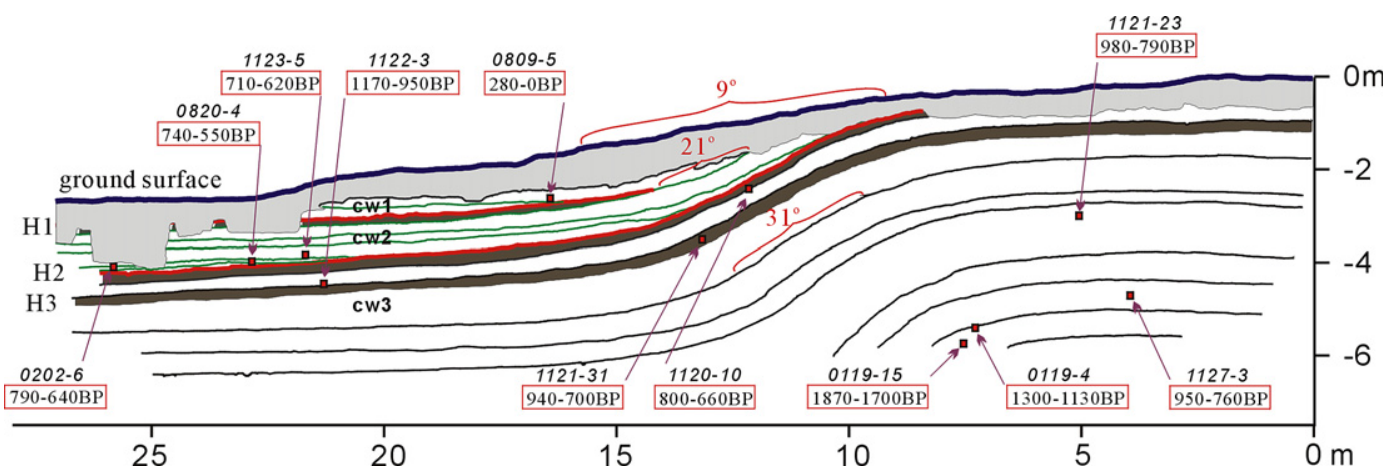

Fig. 9. Sketch of trench-wall highlighting the top of the ground surface, humic soil and mud layers. Soil dip within the forelimb increases from $9^{\circ}$ to $31^{\circ}$. The silty and sandy sediments onlap onto the $\mathrm{H} 1$ and $\mathrm{H} 2$ humic soils form a wedge-shaped alluvium. Radiocarbon dates are used to constrain the timing of $\mathrm{N}-1$ and $\mathrm{N}-2$ paleoseismic events.

and $\mathrm{H} 2$ humic paleosoils across the forelimb. The onlapped relation indicates a folding event after deposition of the $\mathrm{H} 1$ and $\mathrm{H} 2$ paleosoils, whereas stratigraphic correlation of the lower sequence displays about $2.6 \mathrm{~m}$ of vertical relief on both sides of the fault scarp (Fig. 10). Three continuously cored borings drilled to depth of 13 and $43 \mathrm{~m}$ on the hang- ing wall and to $17 \mathrm{~m}$ on the footwall provide further subsurface constraint. Shear zones are located at a depth of $13 \mathrm{~m}$ in borehole 2 and at 20.7 and $30 \mathrm{~m}$ in borehole 1 . We link the shear zones in both the boreholes suggest two faults that $\operatorname{dip} 25^{\circ} \mathrm{E}$ and $49^{\circ} \mathrm{E}$, respectively, are present here (Fig. 10). 


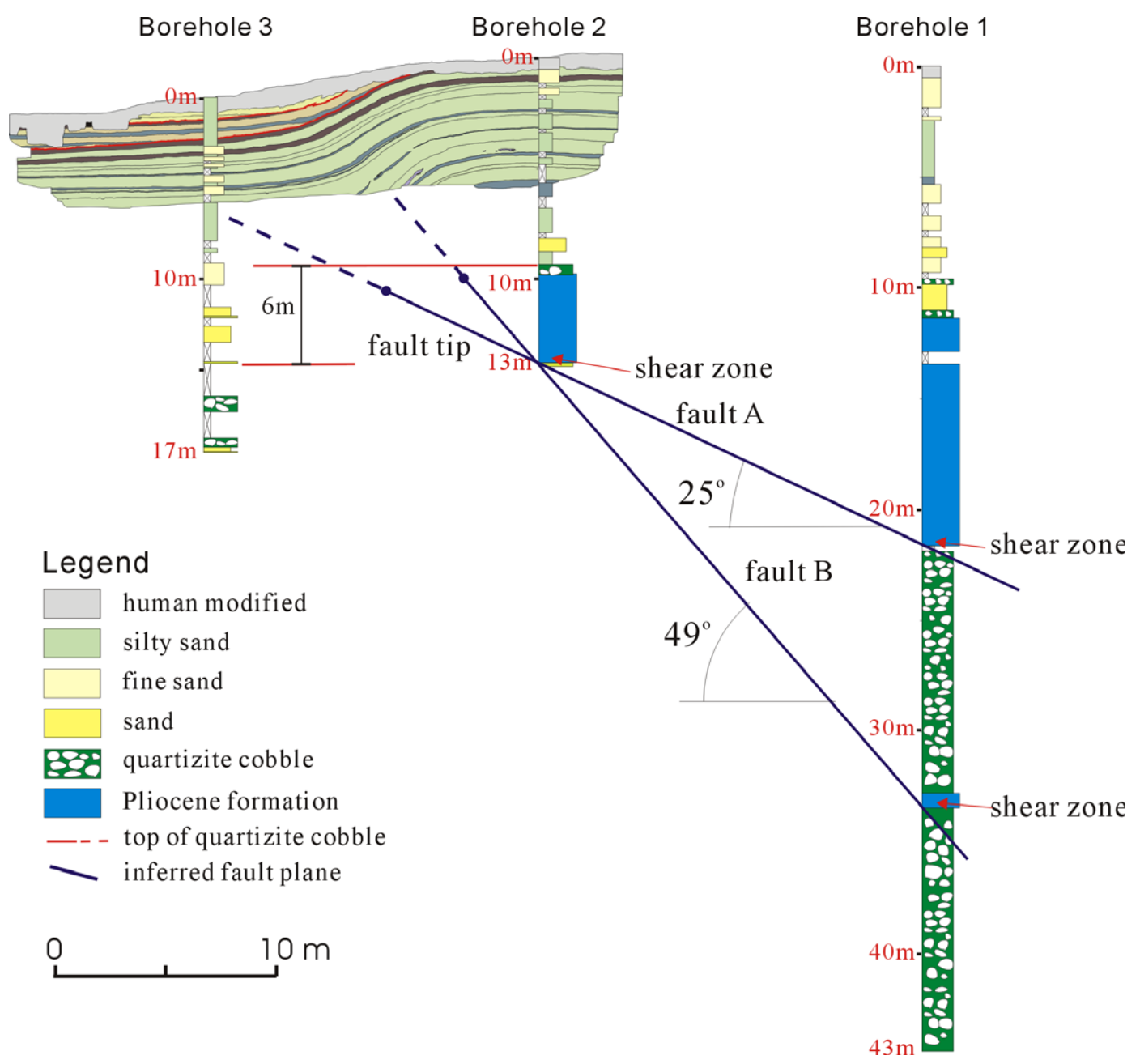

Fig. 10. The well logs of borehole 1 and 2 reveal two fault zones. Fault dip of faults depends on correlation between the borehole of $25^{\circ}$ and $49^{\circ}$ dips. The Pliocene formation shows inclined bedding plane and is weakly sheared. The fluvial cobble deposits between borehole 2 and borehole 3 offset about 6-mhigh in both sides of the fold scarp.

\section{Discussion}

The complex pattern of coseismic folding during the Chichi earthquake sheds light on the evolution of faultpropagation folding at shallow structural levels. The two excavations and well logs indicate at least ten meters of sediments cover on hanging wall, and that additional slip at depth is accommodated along the bedrock-sediment contact (Figs. 6 and 10). The excavations did not reach the fault tip and reveal a fold in thickly unconsolidated deposits below the scarp on the ground surface. The low cohesive strength of the sediments apparently allows trishear faultrelated folding to occur as the predominant mode of deformation within the folded strata in the shallow subsurface. Recent models of fault-propagation folding models (Hedlund, 1997), address variations in fold growth as it relates to fault tip propagation, slip and the distribution of shear (Allmendinger and Shaw, 2000; Champion et al., 2001; Carena and Suppe, 2002). In our study, we document stratigraphic record of coseismic growth folding and sedimentation, related to fault-propagation folding during the Chichi earthquake. The geometry of growth strata provides important constraints on sedimentary and structural interpretations of fold growth by the large earthquakes.

The Siangong-Temple and Shijia sites display a monoclinal fold developed above a thrust fault (Figs. 6 and 10). The excavation displays several alluvial units that onlap paleosoil horizons on the forelimb of a monoclinal fold. The thickness of each alluvial unit gradually decreases across the forelimb forming wedge-shaped deposits. This indicates that folding produces uplift of the fold crest and forelimb with greater deposition on the footwall. The erosion results in an unconformity, such as marked by the Os2 paleosoil at the Siangong-Temple site (Figs. 4 and 5). The presence of old, reworked detrital charcoal (sample 0204-9; Fig. 5) within young footwall units provides additional evidence for erosion of older strata on the fold crest (Chen et al., 2004). This implies that the alluvial stream channel has eroded the upper portion of fold scarp after the coseismic uplift by earthquakes. The depositional architecture of alluvial unit shows an aggradational forward depositional sequence on the forelimb (Figs. 11 and 12). The paleosoil 

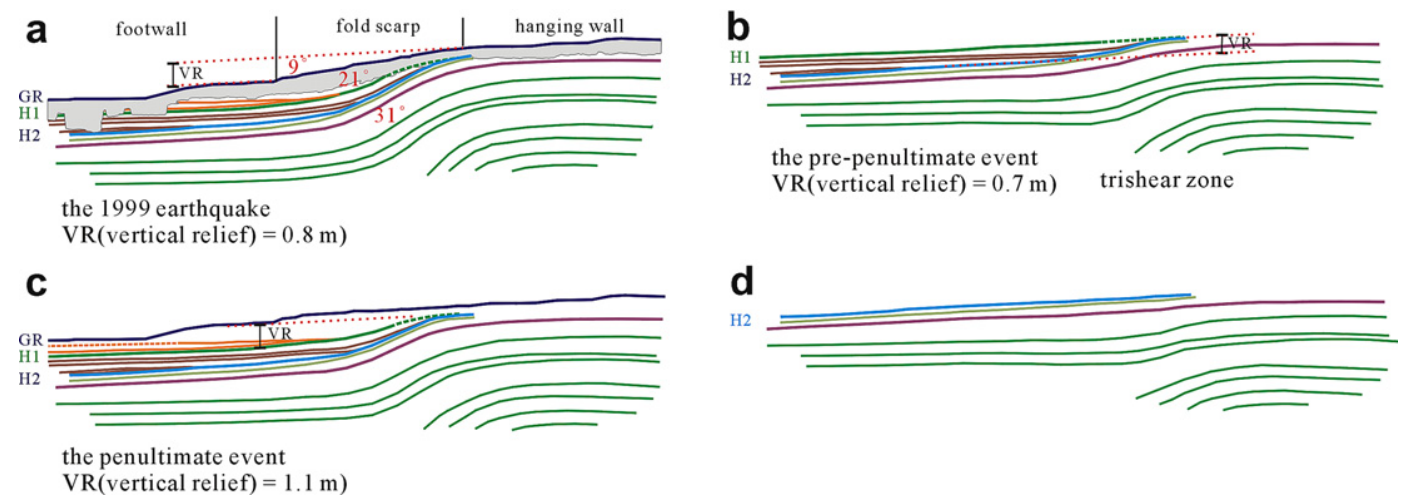

$\operatorname{VR}($ vertical relief $)=1.1 \mathrm{~m})$

Fig. 11. Partial restorations of the Shijia trench. (a) Trench-wall profile after the 1999 earthquake. (b) Restoration of 1999 deformation, fold scarp surface has been restored to a $2^{\circ}$ westward tilt for the pre-1999 ground surface. (c) Restoration of penultimate deformation, H1 paleosoil has been restored to the same slope of pre-1999 ground surface. (d) Restoration of pre-penultimate deformation, H2 paleosoil has been restored to the same slope of the pre-1999 ground surface.
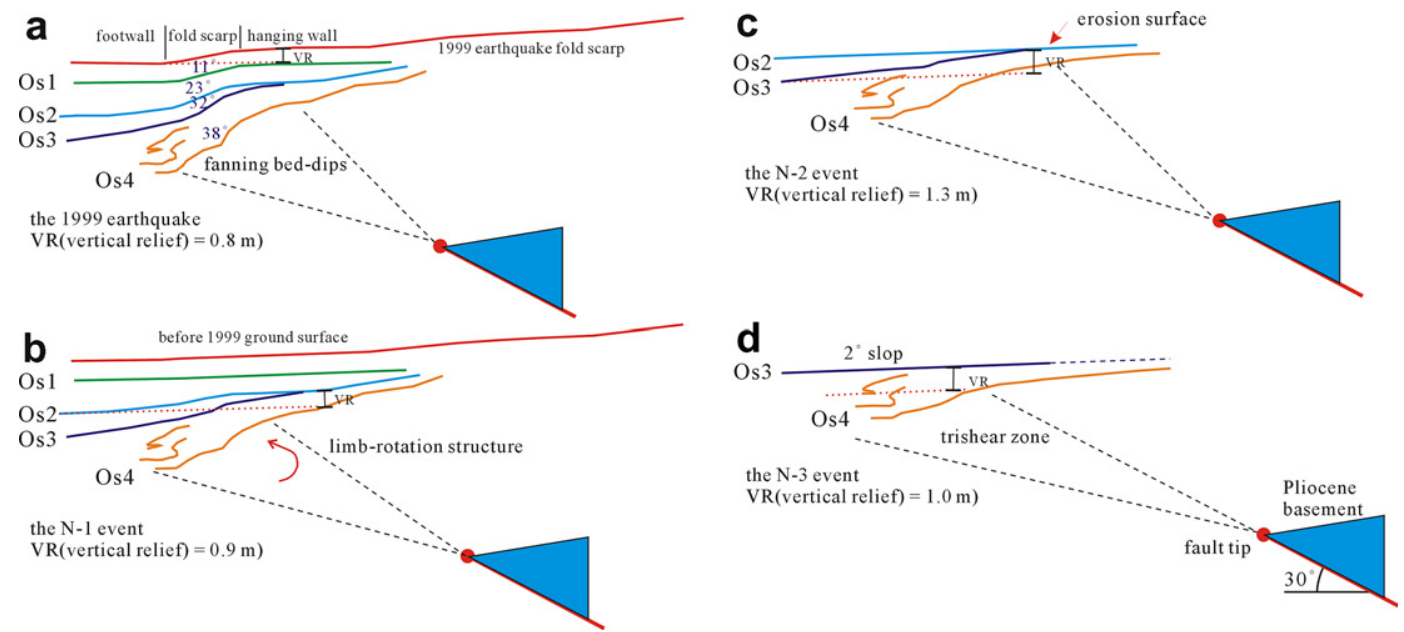

Fig. 12. Partial restorations of the Siangong-Temple trench. Location of fault tip assumes that it is still located at the highest point of basement along the fault plane. Through episodic coseismic folding displays forelimb bed-dips increase, fault tip propagation and onlapped structure. (a) Trench-wall profile after the 1999 earthquake. (b) Restoration of 1999 deformation, fold scarp surface has been restored to a $3^{\circ}$ westward tilt for the pre-1999 ground surface. (c) Restoration of N-1 deformation, Os2 paleosoil has been restored to the same slope of pre-1999 ground surface. (d) Restoration of N-2 deformation, Os3 paleosoil has been restored to the same slope of the pre-1999 ground surface.

horizons bound the alluvial packages and coalesce onto the fold crest. The wedge-shaped deposits represent the postseismic sediments, and the paleosoils form during periods of lower depositional rates that promote soil development (Machette et al., 1992). The wedge-shaped depositional unit therefore brackets coseismic uplift and interseismic deposition and erosion.

Two end-member fault-related folding models are based on kink-band migration with fixed limb dip and limb-rotation mechanisms (Suppe et al., 1992, 1997; Hardy and Poblet, 1994; Novoa et al., 2000). Limb dip during progressive fold growth differentiates the two models (Poblet and Hardy, 1995; Novoa et al., 2000). Based on structural and depositional relations in trench-wall exposures at the Siangong-Temple and Shijia sites, the progressive increase in dip for paleosoils of increasing age is consistent with the limb-rotation model. The trishear deformation model also shows increased bed dips in lower stratigraphic units, (Erslev, 1991; Hardy and Ford, 1997; Allmendinger, 1998), and is supported by the unconformably onlapping structure (Schneider et al., 1996). In addition, fanning of paleosoil dip within the forelimb indicates that the monoclinal fold grew by repeated coseismic deformation. The timing of fold growth is bracketed by the age of the paleosoil horizon and the age of the next depositional package. Deformation began after formation of the paleosoil and terminated prior to deposition of the overlying alluvium. The unconformity at the top of paleosoil horizon represents the upper sequence boundary of alluvium that formed during the interseismic period.

Wedge-shaped alluvial units form by creation of relief during a seismic event and subsequent scarp erosion. Retrodeformation of the top of wedge and capping paleosoil (ground surface, $\mathrm{H} 1$ and $\mathrm{H} 2$ ) provides a record of paleoearthquakes. We reconstructed the alluvial units to their pre-earthquake event using the constant line length method. The restoration is preferable to area balance method which requires constant strata thickness prior to 
deformation. The top line, which represents the post-earthquake ground surface, has been restored to a $2^{\circ}$ westward tilt for the pre-1999 earthquake ground surface. The tilted line length requires matching a constant length of the curvature of the top line (Figs. 11 and 12). The restoration of the 1999 earthquake deformation shows a pre-existing monocline below unit $\mathrm{cw} 1$, and the unit $\mathrm{cw} 1$ still onlapped $\mathrm{H} 1$ paleosoil and the top of unit cw2 which identifies the penultimate event after the deposition of the $\mathrm{H} 1$ paleosoil (Figs. 11a and b). This monocline exhibits $1.1 \mathrm{~m}$ of vertical relief which represents deformation of the penultimate event (Fig. 11b). Using the same method for the H1 paleosoil yields $0.7 \mathrm{~m}$ of vertical relief after the pre-penultimate event. We identify three events including the Chichi earthquake at the Shijia site since 660-800 yr B.P. (sample 112010; Fig. 9). Based on the AMS radiocarbon dates, the two paleoearthquakes occurred at $>280 \mathrm{yr}$ B.P. and 710 $800 \mathrm{yr}$ B.P. (Fig. 13). The lower limit age of penultimate event is not constrained, but the Tsaotun and Mingjian sites to the north and south, respectively, have evidence for the penultimate event formed during 300-500 yr B.P. (Fig. 13).

Onlap of wedged deposits suggest three paleoearthquake events at the Siangong-Temple site during the past 1810 1960 yr B.P (sample 0120-3; Fig. 5). Restoration of paleosoil (Os1, Os2, Os3, and Os4) indicates the original depositional surface had a gentle westward-dipping slope of approximately $2^{\circ}$. Restoration of each paleosoil yields $0.8,0.9,1.3$, and $1.0 \mathrm{~m}$ of vertical relief after each earthquake event (Figs. 12a-d). Previous work at the Pineapple site north of the Siangong-Temple site (Fig. 1) suggests that the penultimate $(\mathrm{N}-1), \mathrm{N}-2$, and $\mathrm{N}-3$ events occurred between 150 $430 \mathrm{yr}$ B.P., $<830 \mathrm{yr}$ B.P., and $1710-1900 \mathrm{yr}$ B.P. (Fig. 13; Chen et al., 2003b, 2004). It is possible that the three events at the Pineapple site occurred at the Siangong-Temple site (Fig. 13), but we do not have age control for the middle two depositional wedges (Fig. 5). Comparing previous studies

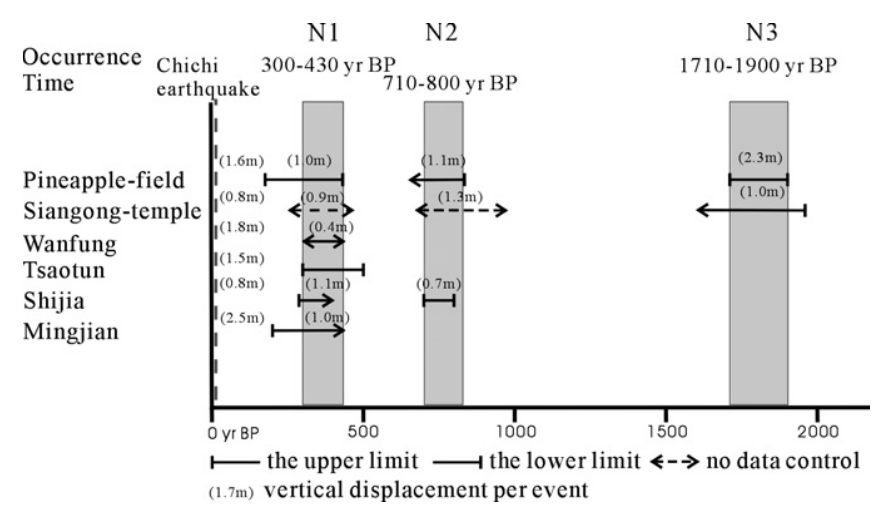

Fig. 13. Event correlation the Chelungpu fault based upon paleoseismological data (Fig. 1). Radiocarbon dating constraints for the paleoearthquake events. Black bars show the age range of radiocarbon date from samples. N1, N2, and N3 events indicate paleoearthquake events in many trenches, the time estimate corresponds to the shaded area. Tsaotun trench excavated by Ota et al. (2001). Pineapple, Wanfung and Mingjian trenches excavated by Chen et al. (2001a,b, 2004). indicates that most sites have evidence for the paleoearthquake events occurring 300-430yr B.P. (N1) and 710$800 \mathrm{yr}$ B.P. (N2). The oldest event (N3, 1710-1900 yr B.P.) is seen at only two sites (Fig. 13).

The slip on the fault can be determined from the vertical relief and fault dip. Above all, we seek to restore existing deformation for each earthquake event as measured by vertical relief. Our results are consistent with results from the measured vertical offsets of the 1999 rupture where common difference range is from several decimeters to three meters (Fig. 1). Displacement variation in the surface rupture causing by the fault plane geometry may be a reflection of fault segmentation. The average slip rate can also be determined for the time interval since the last event. At the Siangong-Temple site, the radiocarbon dates indicates that the older event occurred between 1810 and $1960 \mathrm{yr}$ B.P., and the total vertical offset is at least $4.0 \mathrm{~m}$. Therefore we are able to estimate that the vertical uplift rate is about $2.1 \pm 0.1 \mathrm{~mm} / \mathrm{yr}$. Using the vertical displacement divided by the fault dip of $30^{\circ}$ can obtain the slip rate of $4.2 \mathrm{~mm} / \mathrm{yr}$ for the past $2 \mathrm{ka}$.

The well $\log$ of borehole 1 at the Shijia site indicates that two shear zones are located at the depth 20.7 and $30 \mathrm{~m}$. Based on the depth of fault zone between borehole 2 and borehole 1, it shows two fault planes that have fault dips of about $25^{\circ}$ for fault A and $49^{\circ}$ for fault B (Fig. 10), however, we cannot determine which of the two faults formed the fold. Extension of the fault plane to the ground surface suggests fault B tip is related to the fold axis. Here we assume that the fold at the Shijia site was formed by shear above fault $B$. Based on the fault dip and total vertical offsets during the past $0.8 \mathrm{ka}$, the vertical uplift rate is $3.4 \pm 0.2 \mathrm{~mm} / \mathrm{yr}$, and the slip rate is $4.5 \mathrm{~mm} / \mathrm{yr}$. The fault dip at depth is different in the two trenches, the previous excavations displayed the variation of fault dip ranging from $22^{\circ}$ to $49^{\circ}$. Variations in fault dip along the underlying fault should be reflected by the buried deposits near the surface.

\section{Conclusion}

Coseismic deformation at the leading edge of a propagating thrust fault is recorded by syntectonic sediments. Surface deformation strongly controls sediment accumulation and fault tip propagation. Stratigraphic relations display onlap and unconformities that preserve the record of punctuated fold growth and subsequent deposition. Progressively steepening of the wedges produced during earthquakes suggests that the fold scarp was produced by past earthquakes. The combination of trench-wall excavations, continuous cored borings and sequential restoration provide evidence for coseismic folding events. Results of the paleoseismological analyses can be identified three large paleoearthquake events occurring 300-430, 710-800, and $1710-1900 \mathrm{yr}$ B.P. The vertical offsets from the Shijia site are $0.8 \mathrm{~m}$ for the 1999 rupture and 1.1 and $0.7 \mathrm{~m}$ for the paleoearthquake events, and the Siangong-Temple site is $0.8 \mathrm{~m}$ for the 1999 rupture, $0.9,1.3$, and $1.0 \mathrm{~m}$ for the paleo- 
earthquake events, respectively. The slip rate on the Siangong-Temple and Shijia sites is thus 4.2 and $4.5 \mathrm{~mm} / \mathrm{yr}$, respectively.

\section{Acknowledgements}

This study was financially supported by National Science Council of Taiwan under Grant NSC-91-2119-M-002022 and by Central Geological Survey of Taiwan Grant under CGS-91ECA38104. We thank an anonymous reviewer and Professor Andrew Meigs for their critical and valuable comments on the manuscript.

\section{References}

Allmendinger, R.W., 1998. Inverse and forward numerical modeling of trishear fault-propagation folds. Tectonics 17, 640-656.

Allmendinger, R.W., Shaw, J., 2000. Estimation of fault propagation distance fold shape: implications for earthquake hazard assessment. Geology $28,1099-1102$.

Carena, S., Suppe, J., 2002. Three-dimensional imaging of active structures using earthquake aftershocks: the Northridge thrust, California. Journal of Structural Geology 24, 887-904.

Central Geological Survey, 1999. Report of the geological survey of the 1999 Chi-Chi earthquake. Central Geological Survey, Taiwan, pp. 315.

Champion, J., Mueller, K., Tate, A., Guccione, M., 2001. Geometry, numerical models and revised slip rate for the Reelfoot fault and trishear fault-propagation fold, New Madrid seismic zone. Engineering Geology 62, 31-49.

Chen, W.S., Chen, Y.G., Liu, T.K., Huang, N.W., Lin, C.C., Sung, S.H., Lee, K.J., 2000. Characteristics of the Chi-Chi earthquake ruptures. Special Publication Central Geological Survey 12, 139-154.

Chen, W.S., Chen, Y.G., Cheng, H.C., 2001a. Paleoseismic study of the Chelungpu fault in the Mingjian area. Western Pacific Earth Sciences $1,351-358$.

Chen, W.S., Chen, Y.G., Chang, H.C., Lee, Y.H., Lee, C.C., 2001b. Paleoseismic study of the Chelungpu fault in the Wanfung area. Western Pacific Earth Sciences 1, 43-72.

Chen, W.S., Chen, Y.G., Lee, C.T., Hsieh, M.L., Chyi, S.J., 2001c. Neotectonic and Paleoseismic studies. Central Geological Survey 2001 Final Report, pp. 107.

Chen, W.S., Huang, B.S., Chen, Y.G., Lee, Y.H., Yang, C.N., Lo, C.H., Chang, H.C., Sung, Q.C., Huang, N.W., Lin, C.C., Sung, S.H., Lee, K.J., 2001d. Chi-Chi earthquake, 1999 September 21: a case study on the role of thrust-ramp structures for generating earthquakes. Bulletin of the Seismological Society of America 91, 986-994.

Chen, Y.G., Chen, W.S., Lee, J.C., Lee, Y.H., Lee, C.T., Chang, H.C., Lo, C.H., 2001e. Surface rupture of 1999 Chi-Chi earthquake yields insights on active tectonics of central Taiwan. Bulletin of the Seismological Society of America 91, 977-985

Chen, Y.G., Chen, W.S., Wang, Y., Lo, P.W., Liu, T.K., Lee, J.C., 2002. Geomorphic evidence for prior earthquakes: lessons from the 1999 Chichi earthquake in central Taiwan. Geology 30, 171-174.

Chen, W.S., Chen, Y.G., Shih, R.C., Liu, T.K., Huang, N.W., Lin, C.C., Sung, S.H., Lee, K.J., 2003a. Thrust-related river terrace development in relation to the $1999 \mathrm{Chi}$-Chi earthquake rupture, western foothills, central Taiwan. Journal of Asian Earth Science 21, 473-480.

Chen, Y.G., Chen, Y.W., Chen, W.S., Zhao, J.F.H., Zhou, L.P., Li, S.H., 2003b. Preliminary results of long-term slip rates of 1999 earthquake fault by luminescence and radiocarbon dating. Quaternary Science Review 22, 1213-1221.

Chen, W.S., Lee, K.J., Lee, L.S., Ponti, D.J., Prentice, C., Chen, Y.G., Chang, H.C., Lee, Y.H., 2004. Slip rate and recurrence interval of the Chelungpu fault during the past 1900 years. International Quaternary 115-116, 167-176.

Chiu, H.T., 1971. Folds in the northern half of western Taiwan. Petroleum Geology of Taiwan 8, 7-19.

Deng, Q., Zhang, P., Xu, X., Yang, X., Peng, S., 1996. Paleoseismology of the northern piedmont of Tianshan Mountains, northwestern China. Journal of Geophysical Research 101, 5895-5920.

Erslev, E.A., 1991. Trishear fault-propagation folding. Geology 19, 617620 .

Hardy, S., Poblet, J., 1994. Geometric and numerical model of progressive limb rotation in detachment folds. Geology 22, 371-374.

Hardy, S., Ford, M., 1997. Numerical modeling of trishear fault-propagation folding. Tectonics $16,841-854$

Hedlund, A.C., 1997. Fault-propagation, ductile strain, and displacement-distance relationships. Journal of Structural Geology 19, 249-256.

Kao, H., Chen, W.P., 2000. The Chi-Chi earthquake sequence: active, outof-sequence thrust faulting in Taiwan. Science 288, 2346-2349.

Lee, K.C, 2003. Paleoseismicity of the 1999 earthquake rupture of the Chelungpu Fault. National Taiwan University, Department of Geosciences, MS thesis, pp. 111.

Machette, M.N., Personius, S.F., Nelson, A.R., 1992. Paleoseismicity of the Wasatch Fault zones: a summary of recent investigation, interpretations and conclusions, In Gori, P.L. (Ed.), Assessment of regional earthquake hazards and risk along the Wasatch Front, Utah. U.S. Geol. Surv. Professional Paper 1500, p. A1-A30.

Novoa, E., Suppe, J., Shaw, J.H., 2000. Inclined-shear restoration of growth folds. America Association of Petroleum Geologists Bulletin $84,787-804$.

Ota, Y., Huang, C.Y., Yuan, P.B., Sugiyama, Y., Lee, Y., Watanabe, M., Sawa, H., Yanagida, M., Sasaki, S., Suzuki, Y., Hirouchi, D., Tangiguchi, K., 2001. Trenching study at the Tsaotun site in the central part of the Chelungpu fault, Taiwan. Western Pacific Earth Sciences 1, 487498.

Ota, Y., Chen, Y.G., Chen, W.S., 2005. A review on paleoseismological and active fault study in Taiwan. Tectonophysics 408, 63-77.

Philip, H., Meghraoui, M., 1983. Structural analysis and interpretation of the surface deformations of the El Asnam earthquake of October 10, 1980. Tectonics 2, 17-49.

Poblet, J., Hardy, S., 1995. Reverse modeling of detachment folds: application to the Pico de Aguil anticline in the south central Pyrenees (Spain). Journal of Structural Geology 17, 1707-1724.

Schneider, C.L., Hummon, C., Yeats, R.S., Huftile, G.L., 1996. Structural evolution of the northern Los Angeles basin, California, based on growth strata. Tectonics 15, 341-355.

Stein, R.S., King, G.C.P., 1984. Seismic Potential Revealed by Surface Foldings: 1983 Coalinga, California, Earthquake. Science 224, 869872.

Suppe, J., Chou, G.T., Hook, S.C., 1992. Rates of folding and faulting determined from growth strata, thrust tectonics. In: MaClay, K.R. (Ed.), Chapman and Hall, London.

Suppe, J., Sabat, F., Munoz, J.A., Poblet, J., Roca, E., Verges, J., 1997. Bedby-bed growth by kink-band migration: Sant Llorenc de Morunys, eastern Pyrenees. Journal of Structural Geology 19, 443-461.

Wang, C.Y., Li, C.L., Su, F.C., Leu, M.T., Wu, M.S., Lai, S.H., Chern, C.C., 2002. Structural mapping of the 1999 Chi-chi earthquake fault, Taiwan by seismic reflection methods. Terrestrial, Atmospheric and Oceanic Sciences 13, 211-226. 